\title{
Prediction of Land Erosion Events in the Down Stream Kreung Meureubo Watershed West Aceh District
}

\author{
Muhammad Ikhsan*, Meylis Safriani, Cut Suciatina Silvia, Refvina Dari \\ Faculty of Engineering, Teuku Umar University, Aceh, Indonesia \\ *Corresponding authorE-mail: m.ikhsan@utu.ac.id
}

Manuscript received 15 August 2021; revised 1 Sept 2021; accepted 15 Sept 2021. Date of publication 4 Nov 2021

\begin{abstract}
This study aims to predict the occurrence of erosion in the downstream Krueng Meureubo watershed, West Aceh Regency. Erosion is the loss of topsoil due to rain splash which is analyzed as a factor of rain erosivity, but the occurrence of erosion is not necessarily calculated by the occurrence of rain alone, but many other factors, such as soil erodibility, slope and length of land, land cover and the presence or absence of land conservation efforts. the. The Krueng Meurebo watershed shows a large sediment transport, with an indication that the river is getting shallower caused by sediment deposition at the riverbed, this sediment comes from sediment carried through the process of soil erosion. The method used in analyzing the occurrence of soil erosion in this study is the USLE method and uses a Geographic Information System (GIS). The results obtained are the distribution of erosion rate values in 228 polygons, with the largest erosion rate value occurring in polygon 1 with an erosion rate of 8495.308 tons/ha/year. The smallest erosion rate occurs in polygons $30,34,35,179$, and 180, with an erosion rate of 0 meaning that there is no land erosion event, which occurs in organosol and glehumus and regosol soil types, land cover is settlements and water bodies. It is concluded that the occurrence of erosion in a land is very dependent on the type of soil and the type of land cover. It is recommended for land with large erosion events to take serious land conservation actions so that erosion events can be minimized and do not occur continuously which of course can cause the watershed to become critical. Conservation efforts can be carried out in various ways, one of which is by vegetative means using plants that can reduce the rate of soil erosion.
\end{abstract}

Keywords: Erosion Events, USLE, GIS, Kreung Meureubo Downstream Watershed, Conservation.

\section{Introduction}

Soil erosion is a natural event that occurs on the land surface with various types of land cover. The amount of erosion really depends on several natural factors, namely rain erodibility, soil erodibility, slope and length of the land, but now humans also play an important role in the occurrence of erosion, where land use changes are no less important factors in determining the level of erosion. Erosion is the loss of soil that can be caused by water, wind and rain. The process of erosion is not as simple as the product of erosivity and erodibility, but is also influenced by factors that affect the two variables, namely the nature of rain, soil type, slope, vegetation type, and human activities in relation to land use. The occurrence of erosion is often exacerbated by increased human activities in the location, for example illegal logging, mining activities, plantations in this case opening new land and poor land use [1]. The magnitude of the rate of erosion that occurs on a land with a certain slope and rainfall pattern for various types of soil and land use conditions in the long term can be predicted using the USLE method. This study aims to obtain the value of the rate of soil erosion on oil palm plantations (Elaeis guinensiss Jacq.) which are no longer productive using the USLE method at PTP Nusantara II Tanjung Garbus plantation. Parameters observed included soil physical properties, effective soil depth, prediction of erosion that occurred, erosivity factors, soil erodibility, slope length and slope, crop and land conservation factors, tolerable erosion, and the level of erosion hazard [2] [3].

The change of land use in a watershed into plantations and open land is a human activity that sometimes does not refer to conservation rules [4]. This change certainly has a relatively bad impact on the condition of the watershed itself, one of which is the increase in the incidence of land erosion triggered by high rainfall intensity, changes in land use, the slope of the soil type and the presence or absence of conservation actions on the land [5]. Based on the results of the study then Some recommendations are needed, the erosion picture that occurs every year shows the erosion hazard that occurs is included in the classification of mild erosion. This means that the area around the Dawas watershed has less destructive land use. The community must also be smarter in managing the land around the watershed so that the erosion rate can be reduced even more. To anticipate the occurrence of land erosion, namely by conducting land conservation which aims to increase land productivity to support plant growth and reduce or eliminate negative impacts of land management such as erosion, sedimentation and flooding. Efforts are being made to maintain the presence of ground cover vegetation is a more effective and 
economical way to prevent erosion and the spread of surface erosion [6] [7]. The results showed that the highest erosion rate was found in the use of dry land, which was 2,959.018 tons/ha/year, while the lowest erosion was found in residential land use, which was 29.810 tons/ha/year. The highest and lowest allowable erosion is found in the use of bushland, which are 36.96 tons/ha/year and 6.81 tons/ha/year, respectively. The highest erosion hazard index is found in secondary forest land use, which is 342 tons/ha/year, while the lowest erosion hazard index is found in shrubland land use, which is 1.08 tons/ha/year. There are 3 (three) categories of erosion hazard levels in Merdeka District, namely moderate, high, and very high erosion hazard levels [8] [9] [10].

In recent decades, soil erosion models have been integrated with geographic information systems (GIS) for temporal-spatial analysis of soil erosion transport. The Universal Soil Loss Equation (USLE) has been used in many countries, and the input parameter data are well defined. Rapid erosion is a complex problem that affects the regional environment and economies around the world. Erosion can be evaluated spatially to determine effective land management strategies. The GIS in this study was used to generate accurate estimates of the spatial distribution of USLE parameters [11]. Soil erosion is one of the environmental ecosystem issues that has received a lot of attention recently, where human behavior in managing land such as the current condition of the Upper Cimanuk Sub-watershed is quite alarming if it is not handled and controlled for its spatial use. In relation to obtaining erosion estimation information, qualitative methods in which the analysis is assisted using a Geographic Information System (GIS) is more flexible than other erosion models and its application can be adapted to the characteristics of the study area and data availability. This study uses the Rapid Mapping Method to identify the distribution of erosion hazard based on factors that affect erosion such as land cover, percentage of open land and slopes derived from image analysis and DEM [12]. From the results of this study, the value of Erosivity in the Jumantono area 1628.05 with a prediction of erosion (2.22-72.04) tons/ha/year, Lenvain is13882.44 with erosion prediction (18.92-614.28) ton/ha/year and2143.63 with erosion prediction (2.92-94.85) ton/ha/yr. For land unit 3, 4 and 7 the magnitude of the erosion prediction value has exceeded tolerance value which means it requires conservation action. The direction of the recommended conservation action in land unit 3 is to plant strips of 9 rows of vetiver between the main plants. In land unit 4 and land unit 7, the recommended effort is the application of 60\% straw mulch [13] [14]. Along with the increasing incidence of erosion, it certainly has an impact on sediment transport, most of which enters the river and is deposited in the downstream part of the river. this is marked by the silting of the river that occurs today. Krueng Meurebo in West Aceh Regency has recently experienced frequent overflows of water which have an impact on flooding in the area along the river, this is allegedly due to silting of the river in the downstream part, especially, where the volume of sediment transport is relatively large and is deposited in the downstream part of this river. Erosion is caused by the loss of soil layers due to scouring by rain that occurs on vulnerable land, such as land without good cover, illegal logging and areas where land conversion is carried out. In this study, the Yangs method was used to analyze the acute amount of sediment that occurred along the Krueng Meurebo River, Padang Mancang Village, West Aceh Regency, while the data to be analyzed were data from direct measurements in the field such as river cross-section, flow velocity and bottom sediment sampling using traps. sediment and floating sediment. From the results of the data analysis, the amount of sediment transport that occurs along the Meurebo River in Padang Mancang Village is 52.7634168 tons/year [15] [16]. This study aims to determine the magnitude of erosion and sedimentation results and provide recommendations for land conservation efforts in the Pompong watershed. This study uses the USLE (Universal Soil Loss Equation) method to calculate the amount of erosion that occurs, and the SDR (Sediment Delivery Ratio) method to calculate the amount of sedimentation [17].

\section{Literature Review}

\subsection{Erosion}

Erosion is the process of loss or erosion of soil or parts of soil from one place transported by water or wind to another place. The eroded soil is transported by surface runoff and will be deposited in rivers, irrigation canals, reservoirs, lakes or river mouths. This has an impact on the shallowing of the river, resulting in more frequent flooding in the rainy season and drought in the dry season [18]. Erosion is a series of events, at least three processes, namely the release, transport and deposition of sediment in a place [19].

The erosion process causes a number of sediments to be transported into water bodies/rivers, if erosion and sedimentation occur continuously and without any conservation action, there will be significant natural damage, especially the topsoil, Thus, a large amount of sediment transport will inevitably occur. Forecasts of sediment yields are obtained based on the multiplication between the erosion unit value (based on the mapping unit), the erosion unit area and the Sediment Delivery Ratio value in each sub-watershed [20].

\subsection{Factors Affecting Erosion}

There are at least 4 main factors that cause land erosion, including climate, soil, topography and vegetation/land cover. The main factor that affects the occurrence of erosion in tropical climates such as Indonesia is rain. Rain that falls on the soil surface will cause the destruction of soil aggregates due to the destructive power and degradability of the rainwater. Physically, soil is made up of mineral and organic particles of various sizes. The particles are arranged in the form of a matrix whose pores are approximately $50 \%$ partially filled with water and partly filled with air [21].

\section{Methods}

\subsection{Estimated Erosion Rate Using USLE (Universal Soil Loss Equation) Method}

USLE is a parametric model to predict erosion of a plot of land. USLE allows planners to estimate the average rate of erosion of a particular soil on a steep slope with a certain rainfall pattern for each type of cropping and management actions (soil conservation measures) that may be carried out or are being used [18].

to calculate soil loss for a given location as the product of six principal factors whose most probable values at a given location can be expressed numerically. The erosion variables that can be assessed by these factors vary greatly with each storm event, but the effects of random fluctuations tend to dissipate over an extended period. Due to unpredictable short-term fluctuations in the level of the influencing 
variable, however, the current soil loss equation is substantially less accurate for predictions of certain events than for predictions of long-term averages [22].

The soil loss equation is : $\mathrm{A}=\mathrm{R} \mathrm{KLS} \mathrm{C} \mathrm{P}$

Where:

$\mathrm{A}=$ Amount of eroded soil (tonnes/ha/year);

$\mathrm{R}=$ Rainfall and runoff factor (rain erosivity);

$\mathrm{K}=$ Soil erodibility factor;

$\mathrm{LS}=$ Length and slope factor;

$\mathrm{C}=$ Factors of ground cover vegetation and plant management;

$\mathrm{P}=$ Factors of special soil conservation measures.

Rain erosivity factor $(\mathrm{R})$ is defined as the number of units of rain erosion index in a year. The value of $\mathrm{R}$ which is the destructive power of rain can be determined by the equation

\section{$\mathrm{R}=\sum_{i}^{n} E I_{30}$}

where:

$\mathrm{R}=$ Rain erosion $(\mathrm{Kj} / \mathrm{ha} /$ year $)$;

$\mathrm{n}=$ Number of rain events in a year;

EI30 $=$ Energy interaction with maximum intensity 30 minutes.

Soil erodibility $(\mathrm{K})$ is a factor that shows the resistance of soil particles in exfoliating the soil by the kinetic energy of falling rain [19].

Table 1. K values for several soil types in Indonesia

\begin{tabular}{lll}
\hline No & \multicolumn{1}{c}{ Soil Type } & K \\
\hline 1 & Regosol & 0.40 \\
\hline 2 & Alluvial & 0.47 \\
\hline 3 & Grumusol & 0.20 \\
\hline 4 & Mediterranean and Litosol complex & 0.46 \\
\hline 5 & Latosol reddish yellow & 0.36 \\
\hline 6 & Reddish brown latosol and litosol & 0.43 \\
\hline 7 & Reddish yellow latosol and litosol & 0.36 \\
\hline 8 & Mediteran & 0.31 \\
\hline 9 & Renzina & 0.21 \\
\hline 10 & Litosol & 0.22 \\
\hline 11 & Andosol & 0.12 \\
\hline 12 & Latosol & 0.17 \\
\hline
\end{tabular}

Topographic index factors L and S, each of which is the length and slope of the land to the amount of erosion. The length of the slope refers to the runoff, which is the location where erosion will occur and the possibility of sediment deposition [19].

$L S=L^{1 / 2}\left(0,00138 S^{2}+0,00965 S+0,0138\right)$

where:

$\mathrm{L}=$ length of land $(\mathrm{m})$;

$\mathrm{S}=$ Land slope $(\%)$.

Land cover factor ( C) is a factor that shows the overall effect of vegetation, soil surface conditions and land management on the amount of soil lost (eroded) [19]. For more details on land use factors can be seen in Table 2. 
Table 2. C Value for Various Types of Plants

\begin{tabular}{ll}
\hline \multicolumn{1}{c}{ Type of plant/land use } & C \\
\hline Open ground, no plants & 1,0 \\
\hline Savannah and prairie in good condition & 0,01 \\
\hline Savannah and prairie damaged for grazing & 0,1 \\
\hline Rice field & 0,01 \\
\hline Settlement & 0,000 \\
\hline Dryland farming & 0,400 \\
\hline Rubber plantation & 0,85 \\
\hline Mixed dry land farming & 0,1 \\
\hline Primary dryland forest & 0,001 \\
\hline Secondary dryland forest & 0,005 \\
\hline Swamp Scrub & 0,010 \\
\hline Scrub & 0,3 \\
\hline Plantation & 0,200 \\
\hline body of water & 0,00 \\
\hline farming & 0,4 \\
\hline Coffee with bad ground cover & 0,2 \\
\hline Sugarcane & 0,2 \\
\hline Banana & 0,6 \\
\hline
\end{tabular}

Factor $\mathrm{P}$ is the ratio between the average soil eroded from land that received certain special conservation measures to the average eroded soil from land that is cultivated without conservation measures, provided that other erosion-causing factors are assumed to be unchanged [19]. The value of the $P$ factor in various soil conservation activities can be seen in table 3.

Table 3. P Factor in Various Soil Conservation Activities

\begin{tabular}{|c|c|}
\hline Soil conservation techniques & $\mathbf{P}$ \\
\hline No conservation action & 1 \\
\hline The gulud terrace: cassava & 0,06 \\
\hline Terrace gulud: corn-bean + mulch plant residues & 0,01 \\
\hline Terrace gulud: soybeans & 0,11 \\
\hline $\begin{array}{l}\text { Plants in contour: } \\
\text { a. } 0-8 \% \text { slope } \\
\text { b. slope } 9-20 \% \\
\text { c. }>20 \%\end{array}$ & $\begin{array}{l}0,50 \\
0,75 \\
0,90 \\
\end{array}$ \\
\hline $\begin{array}{l}\text { Crops in lanes: corn-peanut }+ \text { straw waste mulch } \\
\text { a. } 6 \text { tons/ha/year } \\
\text { b. } 3 \text { tons/ha/year } \\
\text { c. } 1 \text { ton/ha/year }\end{array}$ & $\begin{array}{l}0,05 \\
0,30 \\
0,50 \\
0,80\end{array}$ \\
\hline $\begin{array}{l}\text { Plantation crops: } \\
\text { a. Accompanied by a tight ground cover } \\
\text { b. With medium ground cover }\end{array}$ & $\begin{array}{l}0,10 \\
0,50\end{array}$ \\
\hline $\begin{array}{l}\text { Meadow: } \\
\text { a. Well } \\
\text { b. Bad }\end{array}$ & $\begin{array}{l}0,04 \\
0,40\end{array}$ \\
\hline
\end{tabular}

\subsection{Erosion rate analysis}

The estimated erosion rate will be calculated using the Universal Soil Loss Equation (USLE) approach, taking into account rain erosivity, soil erodibility, land length and slope and land cover factors by combining (GIS) as a data analysis tool. with the following calculation steps:

a. The calculation of rain erosivity $(\mathrm{R})$ is calculated by Equations 2.2 to 2.3, by analyzing the maximum daily rainfall in a year (Rmax) calculating the kinetic energy and rainfall intensity;

b. The calculation of the LS factor is calculated by Equation 2.4, looking at the length and slope factor of the land using the tools found in the GIS;

c. The estimated erosion rate will be calculated using the Universal Soil Loss Equation (USLE) approach combined with GIS. 


\section{Result and Discussion}

\subsection{Rain Erosivity}

Rain Erosivity Analysis, the data used is the maximum daily monthly rainfall data per year from 2005-2016. After obtaining the average value of each year, then proceed to find the average value of all years. Based on the analysis carried out, the average daily maximum rainfall obtained is $193.8 \mathrm{~mm}$ or $19.38 \mathrm{~cm}$. After obtaining the results of the calculation of the calculation of the average monthly rainfall, the results of the calculation of the number of rainy days per month on average and the results of the calculation of the average daily maximum rainfall, then proceed with the calculation of the monthly rainfall erosion index. The results of the analysis of rain erosion can be seen in table 4.

Table 4. Calculation Results of Monthly Rain Erosion Index

\begin{tabular}{rcccr}
\hline Year & $\mathbf{P} \mathbf{m a x}(\mathbf{c m})$ & $\mathbf{P b}(\mathbf{c m})$ & $\mathbf{N}(\mathbf{d a y})$ & \multicolumn{2}{l}{ EI } \\
\hline 2005 & 10,60 & 28,53 & 15,000 & 339,591 \\
\hline 2006 & 10,70 & 38,03 & 14,500 & 491,034 \\
\hline 2007 & 13,50 & 24,67 & 11,583 & 365,447 \\
\hline 2008 & 16,50 & 37,80 & 14,417 & 613,928 \\
\hline 2009 & 10,70 & 21,97 & 13,083 & 265,270 \\
\hline 2010 & 10,05 & 37,15 & 14,583 & 460,663 \\
\hline 2011 & 10,50 & 40,92 & 14,333 & 534,230 \\
\hline 2012 & 10,65 & 43,76 & 15,250 & 566,893 \\
\hline 2013 & 8,55 & 38,50 & 14,000 & 450,425 \\
\hline 2014 & 14,60 & 30,80 & 14,917 & 442,023 \\
\hline 2015 & 17,27 & 31,59 & 15,333 & 491,333 \\
\hline 2016 & 19,38 & 37,00 & 15,500 & 629,077 \\
\hline & & & $\sum \mathrm{Ei}=$ & 5649,915 \\
\hline
\end{tabular}

\subsection{Erodibility}

The soil types found in the Krueng Meureubo Hilir Sub-watershed vary, there are 4 types of soil that are part of the Krueng Meureubo Hilir Sub-watershed, namely organosol and gle-humus with an area of 28,808.50 Ha and a K value of 0.47. Regosol with an area of 11.703.77 $\mathrm{Ha}$ and a $\mathrm{K}$ value of 0.40 is the widest type of soil found in this sub-watershed, then there is a red-yellow padsolic with an area of 8.122.72 Ha and a K value of 0.49 , and a red-yellow padsolic complex, latosol and litosol with an area of $377.56 \mathrm{Ha}$ and a $\mathrm{K}$ value of 0.36 are the least types of soil found in this sub-watershed.

\subsection{Processing factor length and slope (LS)}

There are 2 types of slope classes in the Krueng Meureubo Hilir sub-watershed, namely $8 \%$ and $8 \%-15 \%$. The length of the slope of the slope of $8 \%$ is $47651.558 \mathrm{~m}$ and the length of the slope of the slope of $8 \%-15 \%$ is 1364.466 .

The longer the slope of a land causes more surface water to accumulate, so that the surface runoff becomes higher in depth and speed. In addition to increasing the velocity of runoff, the steeper slope of the slope is also able to increase the energy of surface runoff and the number of soil particles that are splashed to the bottom of the slope by the collision of more raindrops.

\subsection{Land Cover Types}

The type of land cover that covers the downstream Krueng Meureubo sub-watershed is very varied, there are 12 types of land cover in this sub-watershed, namely shrubs/shrubs with an area of 14,270.40 ha which is the widest land cover in this sub-watershed, then there is a swamp with an area of $24.67 \mathrm{Ha}$, rice fields with an area of 4,070,40 Ha, ponds with an area of 114.22, swamp scrub with an area of 6,100.22 Ha, secondary swamp forest with an area of 2,297.10 Ha, dry land agriculture with an area of 3,417.88 Ha, secondary dryland forest with an area of 1,903.47 Ha, mixed dry land agriculture with an area of 13,480.26 Ha and open land with an area of $2250.74 \mathrm{Ha}$, water bodies with an area of $492.18 \mathrm{Ha}$ and settlements with an area of $591.35 \mathrm{Ha}$, are the least land cover found in this sub-watershed.

\subsection{Land management Factor $(P)$}

Factor $\mathrm{P}$ is the ratio between the average soil eroded from land that received certain conservation treatment to the average eroded soil from land that is cultivated without conservation action, provided that other erosion-causing factors are assumed to be unchanged. The assessment of factor $\mathrm{P}$ in the field is easier when combined with factor $\mathrm{C}$ because in reality, the two factors are closely related. For the process of analyzing the estimated erosion rate for this sub-watershed, the processing of land factor $(\mathrm{p})$ is taken a value of 1 where this value represents land that is being processed without conservation action.

\subsection{Estimated Erosion Rate}

The variation in the value of the erosion rate obtained from the analysis process is highly dependent on the determinants of the USLE, namely from the high value of rain erosivity, and also from the soil type factor in the polygon with the largest erosion rate, namely the 
red yellow podzolic soil type. In addition, the type of land cover also has a big influence. High erosion rates occur in open land. Map of the distribution of land erosion can be seen in Figure 1.

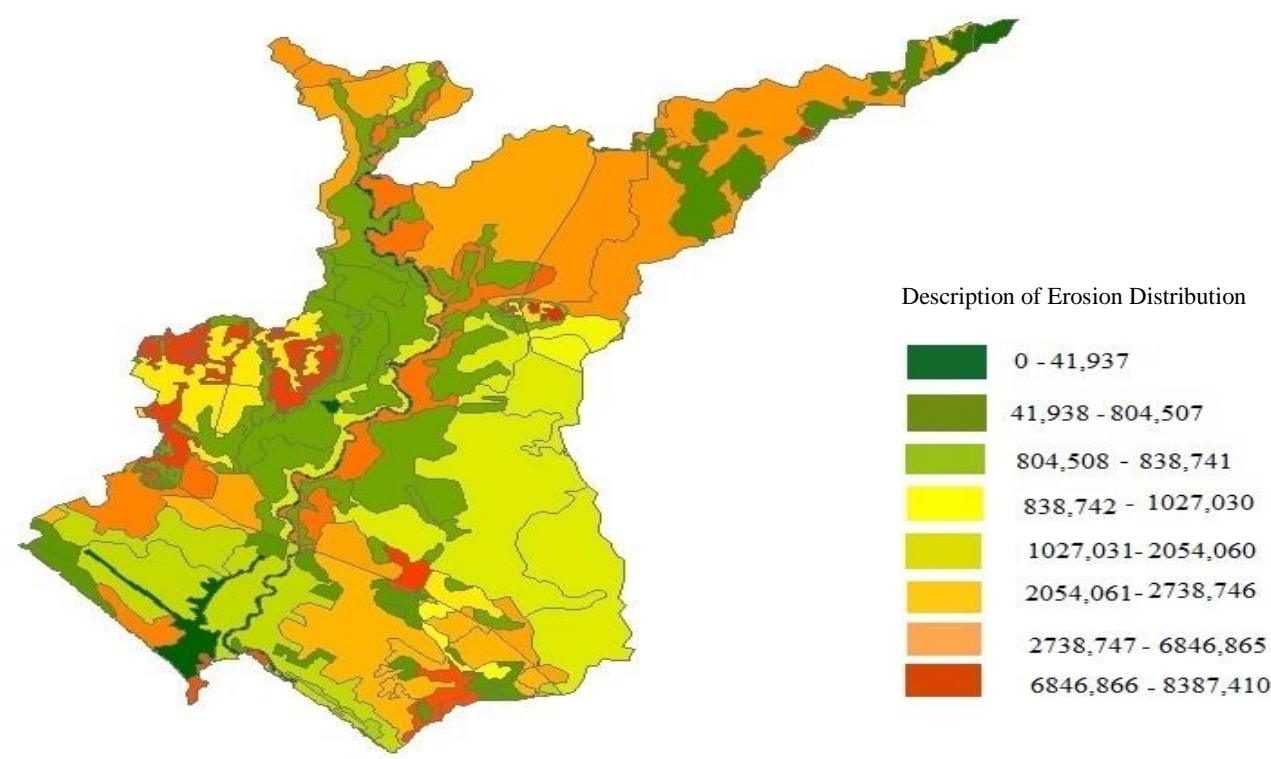

Fig 1. Map of the distribution of land erosion

The GIS erosion rate value in the Krueng Meureubo watershed was obtained from analysis using the USLE method and assisted by GIS software, with the largest erosion rate value occurring in polygon 1 with an erosion rate of 8387,410 tons/ha/year. Some of the lowest erosion rates occurred in polygons $30,34,35,179,180$, with an erosion rate of 0 .

The results of this erosion rate analysis were carried out with a combination of USLE and assisted by GIS software which greatly facilitated the relevant agencies in determining the areas in the downstream Krueng Meurebo Sub-watershed for erosion control efforts.

\section{Conclusion}

The average annual rainfall is obtained by using the value of the average daily rainfall per month, with the calculation result of 34.2251 $\mathrm{cm}$. The number of rainy days is obtained from the number of rainy days per month, with a calculation result of 14.375 days. And the maximum rainfall is obtained from the maximum monthly rainfall, with the calculation result of $19.38 \mathrm{~cm}$. The type of soil found in the Krueng Meureubo Hilir Sub-watershed varies, there are 4 types of soil, namely organosol and glehumus, Regosol, red-yellow padsolic and red-yellow padsolic complex, latosol and litosol. There are two types of slopes in the downstream Krueng Meureubo Sub-watershed, namely the slope of $8 \%-15 \%$ with an area of $127.10 \mathrm{Ha}$, and a slope of $8 \%$ with an area of 48,885.45 Ha. The type of land cover that covers the Krueng Meureubo sub-watershed is very varied, there are 12 types of land cover, namely shrubs/shrubs, swamps, rice fields, swamp scrub, secondary swamp forest, dry land agriculture, secondary dry land forest, mixed dry land agriculture, soil open, bodies of water and settlements. The distribution of erosion rate values is in 228 polygons, with the largest erosion rate occurring in the polygon 1 section with an erosion rate of 8495,308 tons/ha/year, with red yellow podzolic soil types and also occurs in open land cover where land conditions without good land cover and no conservation measures. And the smallest erosion rate occurs in polygons $30,34,35,179$, and 180 , namely the erosion rate of 0 , this occurs in organosol and glehumus soil types and regosol land cover settlements and water bodies.

\section{Acknowledgement}

First of all, the author would like to thank ALLAH SWT who has given the blessing of health and opportunity to the author so that the author can complete this research, then the author also thanks the research team who were very instrumental in completing this article, from data collection, analysis and editing of articles to end. to the Dean of the Faculty of Engineering Dr. Ir. M. Isya, MT, the authors thank you for your support so that we can do this research, we thank the Chancellor of the University of Teuku Umar Prof. Dr. Jasman $\mathrm{j}$ Ma'ruf, SE, MBA for the opportunity, Last but not least to all those who have helped in this research process.

\section{References}

[1] A. Azmeri, E. Meilianda, and M. Ikhsan, "Analisis Sebaran Erosi Lahan dan Upaya Konservasi DAS dengan Sistem Vetiver," Konf. Nas. Tek. Sipil, vol. 2, no. Transportas-Geoteknik-Material-Sumber Daya Air, pp. 26-35, 2014.

[2] U. M. Harahap, D. Lailan, and S. Nasution, "PENDUGAAN LAJU EROSI DENGAN METODE USLE PADA LAHAN TANAMAN KELAPA SAWIT ( Elaeis guinensiss Jacq .) YANG SUDAH TIDAK PRODUKTIF DI PERKEBUNAN PTP NUSANTARA II TANJUNG GARBUS,” vol. 6, no. 3, pp. 637-644, 2018. 
[3] R. Candra Fitrian and A. Sumarno, "Study of the Effect Clay Substitution with Wood Sawdust and Hydroton on Compressive Strength, Density and Water Absorption of Red Brick Case Study of Traditional Red Brick Industry in Singgahan Village," Int. J. Eng. Sci. Inf. Technol., vol. 1, no. 1, 2021, doi: 10.52088/ijesty.v1i1.103.

[4] R. Dewi, N. Sylvia, and M. Riza, "The Effect of Rice Husk and Saw Dusk Filler on Mechanical Property of Bio Composite from Sago Starch,” Int. J. Eng. Sci. Inf. Technol., vol. 1, no. 3, 2021, doi: 10.52088/ijesty.v1i3.113.

[5] S. Ikhsan, Muhammad, Meidia, Refiyanni dan Reni, "Analisis Tingkat Bahaya Erosi Lahan Pada Daerah Aliran Sungai Krueng Seunagan Kabupaten Nagan Raya,” no. September, pp. 18-19, 2018.

[6] Msy Efrodina R Alie, "Kajian Erosi Lahan Pada DAS Dawas Kabupaten Musi BanyuAsin - Sumatera Selatan,” no. 1975, pp. 749$754,2015$.

[7] R. Rinaldy and M. Ikhsan, "Determinant Analysis Of Conflict On Project Results In Aceh Province," Int. J. Eng. Sci. Inf. Technol., vol. 1, no. 1, 2021, doi: 10.52088/ijesty.v1i1.37.

[8] Patrianus Khristian Sumule, "Kajian Tingkat Bahaya Erosi Untuk Arahan Konservasi Tanah Pada Berbagai Tipe Penggunaan Lahan Di Kecamatan Merdeka Kabupaten Karo,” Экономика Региона, vol. 2, no. July, p. 32, 2012.

[9] M. Ayung Tama, M. I. Setiawan, and S. Budi Wasono, “Analysis Of The Performance East Circle Road Of Sidoarjo,” Int. J. Eng. Sci. Inf. Technol., vol. 1, no. 2, 2021, doi: 10.52088/ijesty.v1i2.53.

[10] M. Isradi, N. Aulia Tarastanty, W. Budi Dermawan, A. Mufhidin, and J. Prasetijo, "Performance Analysis of Road Section and Unsignalized Intersections On Jalan Cileungsi Setu and Jalan Raya Narogong," Int. J. Eng. Sci. Inf. Technol., vol. 1, no. 2, 2021, doi: 10.52088/ijesty.v1i2.108.

[11] Azmeri, S. Legowo, and N. Rezkyna, "Interphase Modeling of Soil Erosion Hazard Using a Geographic Information System and the Universal Soil Loss Equation,” J. Chinese Soil Water Conserv., vol. 51, no. 2, pp. 65-75, 2020, doi: 10.29417/JCSWC.202006_51(2).0003.

[12] Razali Rahmat, "Studi Bahaya Erosi Tanah dengan Metode Pemetaan Cepat (Rapid Mapping) di Sub DAS Cimanuk Hulu.," Maj. Geogr. Indones. ISSN 0125-1790, vol. 2, no. 2, pp. 149-168, 2013.

[13] A. Widodo, Komariah, and J. Suyana, "Metode USLE untuk Memprediksi Erosi Tanah dan Nilai Toleransi Erosi Sebuah Sistem Agricultural di Desa Genengan Kecamatan Jumantono Karanganyar," Agrosains, vol. 17, no. 2, pp. 39-43, 2015.

[14] Z. Azmi, “Artificial Neural Network Model For Wind Mill,” Int. J. Eng. Sci. Inf. Technol., vol. 1, no. 3, 2021, doi: 10.52088/ijesty.v1i3.84.

[15] M. Ikhsan, M. Safriani, and N. K. Fitrah, "Study of Sediment Transport in Krueng Meureubo River of Padang Mancang Village Kaway XVI Sub District Aceh Barat District,” J. Phys. Conf. Ser., vol. 1625, no. 1, pp. 0-6, 2020, doi: 10.1088/1742$6596 / 1625 / 1 / 012050$.

[16] S. Akter, M. A. Hossain, and M. M. Rahman Redoy Akanda, “A Noble Security Analysis of Various Distributed Systems,” Int. J. Eng. Sci. Inf. Technol., vol. 1, no. 2, 2021, doi: 10.52088/ijesty.v1i2.101.

[17] B. Oktasandi, E. S. Hisyam, and I. Gunawan, "Analisis Erosi Pada Daerah Aliran Sungai (Das) Pompong Kabupaten Bangka," FROPIL (Forum Prof. Tek. Sipil), vol. 7, no. 2, pp. 70-84, 2019, doi: 10.33019/fropil.v7i2.1625.

[18] S. Arsyad, "Konservasi Tanah dan Air Cetakan III. Bogor: IPB Press." 2012.

[19] C. Asdak, "Hidrologi dan Pengendalian Daerah Aliran Sungai. Yogyakarta: Gadjah Mada University Press.” 2007.

[20] R. M. Zulfa Fauzi and M. Maryono, "Kajian Erosi Dan Hasil Sedimen Untuk Konservasi Lahan DAS Kreo Hulu," J. Pembang. Wil. Kota, vol. 12, no. 4, p. 429, 2017, doi: 10.14710/pwk.v12i4.13508.

[21] Suripin, Pelestarian Sumber Daya Tanah dan Air, no. 2002. 2001.

[22] D. D. Wischmeier, W. H., and Smith, "Predicting rainfall erosion losses-a guide to co,..,ervation planning. U.S. Department of Agriculture, Agriculture Handbook No. 537.”. 